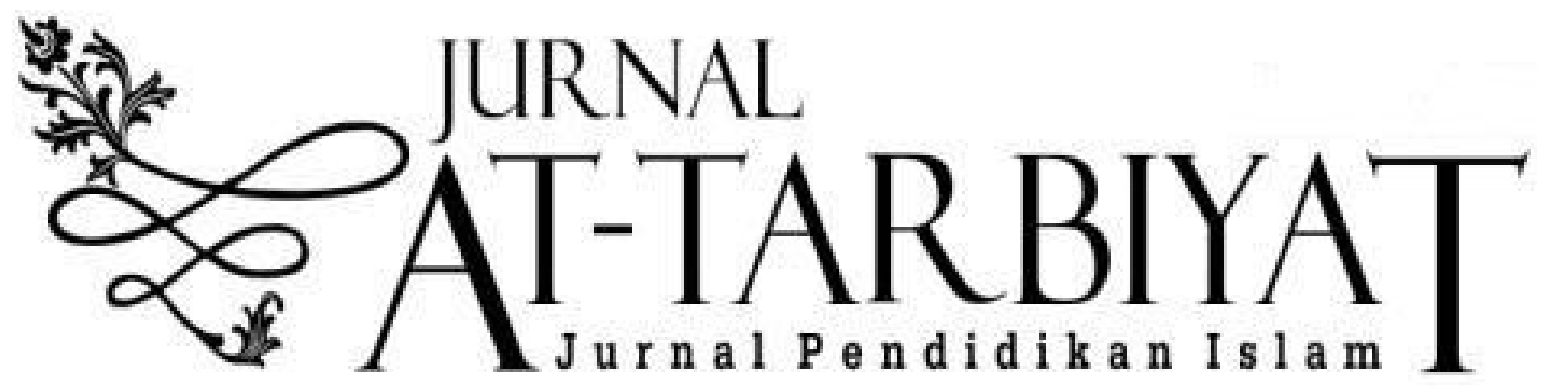




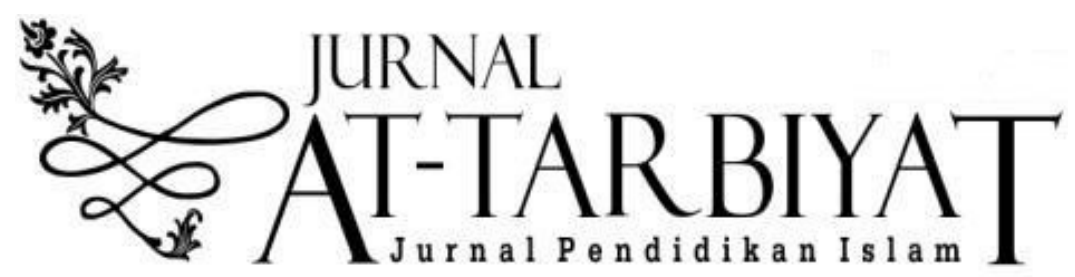

Editorial Team:

Editor in-Chief

Adi Wibowo, STAI An- Nawawi

Purworejo

\section{Editorial Board}

Badrudin, UIN Sunan Gunung Djati Bandung

Imam Machali, UIN Sunan Kalijaga Yogjakarta

Sri Rahmi, UIN Ar-Raniry Banda Aceh

A.Jauhar Fuad, IAI Tribakti Kediri

\section{Managing Editor}

Muhlil Musolin, STAI An- Nawawi

Purworejo

\section{Editor}

Ita Nurmala Sari, STAI An- Nawawi

Purworejo

Ahmad Syafi'i, UIN Sunan Kalijaga

Yogjakarta

Ulumuddin, Unwahas Semarang

Dwi Puji Lestari, STAI Al Hasyimiyyah Jakarta

Sri Sujarotun, STAI An- Nawawi Purworejo

Ali Murfi, UIN Sunan Kalijaga Yogjakarta

\section{Editorial Assistant}

Isnaini, STAI An- Nawawi Purworejo

Mujasim, STAI An- Nawawi Purworejo

\section{Alamat Redaksi:}

Prodi Manajemen Pendidikan Islam, STAIAN Purworejo

Jl. Ir.H. Juanda No. 1 Berjan, Gebang Purworejo 54191 Jawa Tengah»

Tel / fax : (0275)3128428. e-mail: jurnalattarbiyat@gmail.com http://jurnal.staiannawawi.com/index.php/At-Tarbiyat 


\title{
Pembelajaran Pendidikan Agama Islam di Era Revolusi 4.0. Dengan Pendekatan Humanistik di SMP Muhammadiyah Al Mujahidin Gunung Kidul
}

\author{
Eko Prayogo, Suyadi \\ Mahasiswa Magister UIN Sunan Kalijaga Yogyakarta \\ ekoprayogo982.ep@gmail.com \\ yadi.uinjogja@gmail.com
}

\begin{abstract}
Abstrak
Humanistik merupakan konsep terkait manusia sebagai sentral eksistensi. Teori tersebut sangat cocok diterapkan pada pembelajaran, khususnya pembelajaran Pendidikan Agama Islam. Terealisasinya hubungan antar manusia satu dengan manusia yang lain sangat baik. Penelitian ini bertujuan untuk memahami pentingnya belajar Pendidikan Agama Islam di era revolusi 4.0. Pendekatan humanistik perlu diterapakan diera revolusi 4.0 karena dengan majunya teknologi. Metode yang digunakan adalah deskriptif kualitatif. Hasil kajian sementara menunjukkan bahwa pembelajaran Pendidikan Agama Islam di era revolusi 4.0. dengan pendekatan humanistik di SMP Muhammadiyah Al Mujahidin Gunung Kidul cukup baik.
\end{abstract}

Kata Kunci: Pendekatan Humanistik, Era Revolusi 4.0, Pembelajaran PAI.

\begin{abstract}
Humanistic is a concept related to humans as central to existence. The theory is very suitable to be applied to learning, especially Islamic Religious Education learning. The realization of the relationship between humans with other humans is very good. This study aims to understand the importance of learning Islamic Religious Education in the 4.0 revolution era. Humanistic approach needs to be implemented in the area of the 4.0 revolution due to the advancement of technology. The method used is descriptive qualitative. The results of the interim study showed that the learning of Islamic Religious Education in the revolutionary era 4.0. the humanistic approach at the Muhammadiyah Middle School Al Mujahidin Gunung Kidul is quite good.
\end{abstract}


Keywords: Humanistic Approach, Revolutionary Era 4.0, PAI Learning

\section{PENDAHULUAN}

Revolusi 4.0 merupakan segala sesuatu yang dikerjakan mesin atau robot, ketergantungan bidang industri terhadap tenaga manusia mulai berkurang, demikian karena bidang indutri beralih ke tenaga robot dan mesin. Dampaknya ketergantungan terhadap manusia berkurang dalam bidang industri. Untuk mengurangi pengangguran karena semua telah terganti oleh mesin dan robot, manusia dituntut untuk berinovasi dan meningkatkan kualitas diri. Dampak dari berkembangnya revolusi 4.0. informatika teknologi selalu diutamakan, untuk pembelajaran.

Belajar tidak hanya sekedar menghafal dan mengingat, akan tetapi belajar merupakan proses yang ditandai dengan adannya perubahan pada diri siswa. Perubahan sebagai hasil proses yang terjadi pada peserta didik dan diharapkan mampu mengalami perubahan di area yang lebih positive. Perubahan - perubahan yang dimaksud adalah seperti media belajar, perubahan terhadap lingkungan, tingkah laku keterampilan, kecakapan, sikap, daya reaksi, daya penerimaan dan kemampuan.

Teori humanistik adalah suatu tindakan rohani dan jasmani untuk memaksimalkan proses perkembangan pendidikan. Pemahaman sebagai proses pembelajaran dimaknai dengan upaya untuk menguasai khazanah ilmu pengetahuan demi terwujudnya kepribadian yang baik secara universal. ${ }^{1}$ Tidak bisa dipungkiri bahwasanya teori humanistik sudah banyak diterapkan oleh guruguru khususnya guru pendidikan agama Islam. Membahas hubungan guru terhadap siswa tidak terlepas dengan pembelajaran pendidikan agama Islam. Sebagaimana eksistensi pembelajaran agama Islam merupakan pelajaran yang harus ada dipelajaran disekolah.

Dengan berkembangnya zaman, banyak guru yang mengajar ilmu pendidikan agama dengan menggunakan media eletronik,

1 Budi Agus Sumantri, Nurul Ahmad, Teori Belajar Humanistik Dan Implikasinya Terhadap Pembelajaran Pendidikan Agama Islam, (Jurnal Pendidikan Dasar Volume 3. Nomor 2 September 2019), hlm.3. 
guru memberikan materi melalui aplikasi yang telah dibuatnya tanpa menjelaskan atau bertatap muka kepada siswa. Aplikasi yang dibuat oleh guru sangatlah lengkap dan sudah maju menggunakan ilmu teknologi. Dengan aplikasi yang diterapkan kepada siswa, guru mengagapnya semua materi sudah dipahami oleh siswa. Sehubungan pendapat diatas, maka penulis tertarik untuk membahas terkait dengan "Pembelajaran Pendidikan Agama Islam di Era Revolusi 4.0. Dengan Pendekatan Humanistik di SMP Muhammaiyah Al Mujahidin Gunung Kidul"

\section{PEMBAHASAN}

\section{Pengertian Pembelajaran Pendidikan Agama Islam}

Istilah Pembelajaran berasal dari kalimat "instruction". Kalimat intruction dalam bahasa Yunani bermakna instructus. Kata ini mempunyai makna menyampaikan sebuah pemikiran. Instruksional memiliki arti menyampaikan sebuah pikiran atau ide yang telah diolah secara bermakna melalui pembelajaran. ${ }^{2}$ Kegiatan belajar disusun untuk memberikan pengalaman belajar yang melibatkan dalam proses fisik dan mental melalui interaksi antar siswa, siswa dengan guru, sumber belajar dan lingkungan dalam rangka pencapaian target kompetensi dasar.

Pembelajaran dipahami sebagai suatu kegiatan yang melibatkan seseorang dalam memperoleh ilmu pengetahuan dan keterampilan dengan memanfaatkan berbagai sumber untuk belajar. Dalam sebuah pembelajaran melibatkan dua pihak yaitu guru yang berperan sebagai fasilitator dan siswa yang berperan sebagai pembelajar. Kedua pihak tersebut merupakan unsur utama dalam terjadinya sebuah pembelajaran yang kemudian akan melangsungkan proses belajar sesuai rancangan yang sudah disusun sebelumnya. ${ }^{3}$

Menurut Oemar Hamalik menyatakan bahwa pembelajaran merupakan suatu gabungan yang mencakup unsurunsur manusiawi, fasilitas, perlengkapan, material dan prosedur

2 Bambang Warsita, Teknologi Pembelajaran:landasan dan Aplikasinya, (Jakarta: Rineka Cipta, 2008), hlm. 265.

3 Rudi Susilana, Cipta Riyana, Media Pembelajaran (Hakikat, Pengembangan, Pemanfaatan dan Penilaian), (Bandung : CV Wacana Prima, 2018), hlm. 1.

188 Vol. 2, No. 2, Juli - Desember 2019 
yang saling mempengaruhi untuk mencapai target sebuah belajar. ${ }^{4}$ Pembelajaran dalam bagian pendidikan merupakan suatu kegiatan pendidikan yang berupa bantuan rohani dan pemberian bimbingan untuk siswa yang masih memerlukan.

Disamping itu, pembelajaran merupakan sebuah proses menstrasferkan ilmu kepada peserta didik agar dapat mempelajari sesuatu hal yang bermakna untuk diri mereka dan relevan. Selain itu, juga memiliki arti lain yaitu mengembangkan pengalaman atau potensi belajar dimana peserta didik dapat secara aktif menciptakan suatu yang sudah diketahuinya dengan pengalaman yang sudah diperoleh. Dari kegiatan ini, akan mengakibatkan peserta didik mempelajari sesuatu hal yang baru dengan cara lebih efektif dan efesien. ${ }^{5}$

Sedangkan pendidikan merupakan sebuah bimbingan oleh seorang guru terhadap perkembangan rohani dan jasmani peserta didik menuju kepribadian yang lebih unggul. Pendidikan dilihat sebagai salah satu unsur yang mempuyai peran sangat penting dalam menumbuhkan siswa, supaya memiliki kepribadian yang unggul. Dalam ilmu kaidah arab kata pendidikan berasal dari kata ta'dib yang memiliki sebuah arti fokus, dalam makna pendidikan memiliki aspek pengetahuan ('ilmu), pengasuhan (tarbiyah) dan pengajaran (ta'lim). Dalam berkembangnya kata ta'dib, memiliki sebuah arti pendidikan yang telah hilang pernyebarannya. Sebenarnya kata tarbiyah berasal dari kalimat " Robba ,yurabbi, tarbiyatan" yang memiliki makna berkembang tumbuh. Maka dengan terkenalnya kata tarbiyah didalam didunia Islam memiliki arti yang merujuk pada pendidikan Islam. ${ }^{6}$

Pendidikan Agama Islam merupakan suatu subjek pembelajaran yang terdapat pada kurikulum dilembaga pendidikan Indonesia. Karena beragama merupakan suatu dinamika kehidupan yang mampu mewujudkan perpaduan kehidupan antara warga

\footnotetext{
hlm. 40 .

${ }^{4}$ S. Winataputra, Belajar dan Mengajar, (Surakarta: Lima Aksara, 2008). hlm. 157.

${ }^{5}$ Muhaimin dkk, Strategi Belajar Mengajar, (Surabaya: Citra Media, 1996), 1993), hlm. 9.

${ }^{6}$ Zuhairini, dkk. Metodologi Pendidikan Agama Islam, (Solo:Ramadhani,
} 189 Vol. 2, No. 2, Juli - Desember 2019 
negara satu dengan negara yang lain. ${ }^{7}$ Mengutip pendapat Zakiyah Darajat dalam bukunya menyatakan bahwa Pendidikan Agama Islam merupakan proses membina serta membimbing peserta didik untuk memahami ajaran agama Islam secara universal. Sehingga merasakan suatu tujuan yang dapat merealisasikan serta menganggap Islam sebagai pedoman hidup. ${ }^{8}$

Seiring dengan pendapat Zakiyah Derajat, hal yang serupa disampaikan oleh Agus Basri bahwasanya Pendidikan Agama Islam merupakan proses konseling rohani dan jasmani berlandaskan dengan ajaran Islam demi mewujudkan kepribadian yang harmonis dan terpadu. ${ }^{9}$ Begitu pula, Zuhairini berpendapat bahwa Pendidikan Agama Islam merupakan proses membimbing kepribadian peserta didik kearah yang lebih baik secara sistematis dan prakits. ${ }^{10}$

Menurut Nazarudin Rahman ada beberapa point yang harus diperhatikan dalam pembelajaran Pendidikan Agama Islam, yaitu sebagai berikut :11

Pendidikan Agama Islam merupakan proses pengajaran, membimbing serta latihan yang dilaksanakan secara berencana dan sadar sesuai dengan tujuan yang ingin dicapai. Siswa harus mampu untuk memahami pelajaran Pendidikan Agama Islam. Pendidik harus menjalankan tugasnya sebagai mana mestinya pengajaran, bimbingan dan latihan. Aktivitas pembelajaran Pendidikan Agama Islam dituntun untuk meningkatkan pemahaman, keyakinan, pengalaman dan penghayatan ajaran agama Islam.

Ilmu Pendidikan Agama Islam dianggap salah satu komponen penting dalam pembelajaran. Maka dari itu, metode

\footnotetext{
${ }^{7}$ Najamuddin P. Solong, Pengembangan Materi Pendidikan Agama Islam, (Sleman: Teras, 2014), hlm. 14.

${ }^{8}$ Zakiyah Derajat, Ilmu Pendidikan Islam, (Jakarta: Bumi Aksara, 2008), hlm. 87.

9 Agus Basri, Pendidikan Islam sebagai Penggerak Pembaharuan, (Bandung: PT Al Ma’arif, 1984), hlm. 22.

${ }_{10}$ Zuhairini, Metode Pembelajaran Pendidikan Agama Islam, (Malang: UIN Malang Press, 2004), hlm. 11.

11 Nazarudin Rahman, Manajemen Pembelajaram, Implementasi Konsep, Karakteristik dan Metodologi Pendidikan Agama Iskam di Sekolah Umum, (Yogyakarta: Pustaka Felicha, 2009), hlm. 12.
} 
pembelajarannya harus bersifat mengarahkan demi terwujudnya tujuan Pendidikan Agama Islam.

Dari kesimpulan diatas dapat ditarik kesimpulan bahwa pembelajaran Pendidikan Agama Islam merupakan strategi yang dapat digunakan untuk mendorong peserta didik supaya tertarik mempelajari Pendidikan Agama Islam. Pemahaman tersebut dapat berupa, cara beragama dengan baik. Serta bagaimana proses yang baik untuk mempelajari agama. Sehingga mampu membentuk kecerdasan dalam aspek kognitif, psikomotorik dan afektif. 12

\section{Eksitensi Pembelajaran Pendidikan Agama Islam di Era Revolusi 4.0}

Pendidikan diera revolusi 4.0. merupakan suatu istilah yang sering dipakai para pakar pendidikan untuk mendiskripsikan berbagai strategi untuk menghubungkan ilmu teknologi cyber kedalam pelajaran. Hal tersebut, merupakan pendidikan di era revolusi 3.0. (efucation), sebagaimana pandangan Jeff Borden mengatakan bahwa pembelajaran di era revolusi 3.0. sebagaimana di era 4.0. lebih bergerak dalam bidang industri. Sehingga mesin dan manusia diselaraskan untuk memunculkan solusi serta menanamkan inovasi baru khususnya dalam lingkup pendidikan.

Dalam revolusi digital dikatakan dengan adanya sebuah teknologi yang nama lain dari industri 4.0. itu sendiri. Revolusi digital karena adanya proliferasi computer disemua bidang. Di era revolusi industri 4.0. sekarang ini, ada beberapa tantangan yang perlu untuk diperhatikan. Pertama, keadaan teknologi informasi itu sendiri. Kedua, kondisi mesin yang diproduksi. Ketiga, minimnya sebuah keterampilan dalam menjalankan industri. Keempat, kurangnya perhatian dan paham berwenang dalam mengembangkan industri. Kelima, kurangnya lapangan pekerjaan yang diakibatkan oleh industri. ${ }^{13}$

Kata Revolusi industri dipopulerkan oleh Fried Engel dan Louis-Auguste Blanqui dipertengahan abad ke 19 an. Revolusi

${ }^{12}$ Abdul Majid, Dian Andayani, Pendidikan Agama Islam Berbasis Kompetensi (Konsep dan Implementasi Kurikulum 2004), (Bandung: Remaja Rosdakarya, 2006), hlm. 132.

${ }_{13}$ Nurul Hidayati, Urgensi Pendidikan Islam di Era 4.0., (article: may, 2019), hlm, 19. 
industri ini semakin hari semakin berkembang. Hal tersebut, dapat dilihat dari histori revolusi industri itu sendiri. Pada fase pertama 1.0. tahap pada penemuan sebuah mesin yang menitik beratkan mekanisme produksinya. Fase kedua 2.0. mulai menuju pada tahap produksi secara bersamaan yang berhubungan dengan kualitas standarisasi dan control. Fase ketiga 3.0. mulai memasuki tahapan keseragaman secara menyeluruh yang berlandaskan pada intergrasi teknologi. Fase keempat 4.0. tahap ini telah mampu merilis era digital yang memadukan internet dengan manufaktur. ${ }^{14}$

\section{Konsep Pendekatan Humanistik}

Pendidikan humanistik tidak terlepas dengan pemahaman psikologis tentang humanistik. Memahami psikologi humanistik sangatlah dipercaya oleh para ahli sehingga dijadikan pacuan terwujudnya rancangan humanistik. ${ }^{15}$ Humanistik merupakan sebuah paham psikologis yang hadir pada tahun 1950 an semacam kegiatan behavorisme dan psikoanalis. Golongan tersebut secara ekplisit memberikan perhatian khusus psikologi pada dimensi manusia serta konteks manusia dalam perkembangan teori psikologis. Humanistik secara etimologi suatu paham yang terkait dengan manusia. Konsep humanistik diartikan sebagai manusiasime. Secara luas humanistik diartikan sebagai suatu konsep terkait dengan selaku sentral eksistensi.

Dalam dunia pendidikan teori humanistik merupakan istilah yang sudah familiar dikehidupan sosial. Sebagaimana pembahasanya terfokus pada aspek sosial manusia. Pada kenyataannya, teori tersebut berkembang dari paham psikologis, kemudian sangat berpengaruh paham pada pengembangan teori, praktik pembelajaran dan pendidikan sangat dikenal sebagai paham humanistik. Pada teori humanistik, suatu pembelajaran dianggap sukses apabila peserta didik mampu memahami lingkungan serta kepribadiaanya. Dalam proses pembelajaran peserta didik harus berusaha dengan sungguh-sungguh supaya

\footnotetext{
14 Sigit Priatmoko, "Memperkuat Eksitensi Pendidikan Islam Di Era 4.0," Jurnal Studi Pendidikan Islam Vol.01, No. 02 (2018): 10.

15 Ratna Syifaa Rahmahana, "Psikologi Humanistik Dan Aplikasi Pendidikan,” Dalam El- Tarbawi: Jurnal Pendidikan Islam 1, No. 1 (n.d.): 16. 
mampu mencapai target aktualisasi diri dengan baik. ${ }^{16}$

Bagi pelaksana teori humanistik, proses belajar senantiasa bermuara pada konsep manusia itu sendiri. Pada hakikatnya teori tersebut lebih banyak membahas tentang proses belajar dari bentuk yang ideal. Seyogyanya teori apapun,dapat digunakan untuk mendidik selama tujuannya mengarah pada aktualisasi diri manusia yang baik. Adapun ciri-ciri dari konsep belajar humanistik adalah sebagai berikut: 1) kehadiran manusia mempunyai dua pokok penting diantaranya yakni pada diri dan berada untuk diri sendiri. 2) adanya kebebasan memilih tentang apa yang akan dipelajari. 3) kesadaran, dengan adanya kesadaran manusia diharapkan mampu untuk mengetahui apa yang akan dilakukan kedepannya. ${ }^{17}$

Hubungan Pembelajaran Pendidikan Agama Islam di Era Revolusi Di era revolusi industri 4.0. tidak sebatas mengubah tatanan kebiasaan dan pola kehidupan masyarakat, akan tetapi juga mendorong timbulnya berbagai idea-idea baru dalam lingkup keagamaan (religiusitas), keyakinan serta nilai-nilai sosial dalam kehidupan. Munculnya dari idea-idea baru yang terkonsep dari dunia pendidikan harus dipelajari secara mandalam, selaku agama Rahmatan lil 'alamin menjadi hal yang urgen untuk diperhatikan dalam menghadapi perkembangan zaman.

Seharunya, pada faktanya pendidikan Islam kurang memperhatikan timbulnya pemikirn yang kritis, padahal Islam dapat menjawab bentuk tantangan perubahan zaman. Sebagaimana dalam Islam, Al Quran dijadikan sebagai pedoman hidup yang berlaku hingga akhir zaman. Sekiranya, semakin zaman berkembang dengan teknologi informasi global, maka sangat banyak peluang yang dapat dipetik pada pendidikan nasional khususnya pendidikan Islam. Kehadiran Islam menjadi inti penting dalam dunia pendidikan, Sebagaimana Islam mampu memasuki semua aspek perkembangan dunia. Islam mampu memunculkan

${ }^{16}$ dkk Agus Akmal, "Pembelajaran Pendidikan Agama Islam Humanistik Dengan Pendekatan Active Learning Di MTs N 1 Bombang,” Jurnal Dirkursus Islam Vol. 06, No. 03 (2019): 405.

${ }^{17}$ Mohammad Muclish Solichin, “Teori Belajar Humanistik Dan Aplikasinya Dalam Pendidikan Agama Islam,” Jurnal Studi Islam Al Studi Islam Vol.05, No. 01 (2018): 4-5.

193 Vol. 2, No. 2, Juli - Desember 2019 
eksistensinya ditengah-tengah keanekeragaman global, terutama di dunia pendidikan. ${ }^{18}$

Akurat teknologi informasi merupakan fasilitas untuk mendapatkan sebuah informasi yang akurat dengan tidak adanyan penyaringan informasi dari sisi agamanya, maka informasiinformasi yang beredar akan kurang bernilai. Hal tersebut dapat diperhatikan dari banyaknya informasi yang menampakkan hal-hal negative, seperti film, iklan serta produk-produk hiburan lainnya. Dalam Mengahadapi hal tersebut, sangatlah dibutuhkan pengembangan budaya kritis dan religius yang mampu memenuhi kebutuhan hiburan serta memperhatikan nilai estetika dalam perkembanganya media-media era sekarang.

Sejarah juga mengatakan bahwasanya pola kehidupan masyarakat selaras dengan perkembangan ilmu pengetahuan teknologi. Semakin bertambahnya penduduk, serta penyebaranya informasi keseluruhan media sosial. Sementara ajaran atau pedoman keragaman dalam hal ini Islam hanya fakum tanpa ada perubahan ruang lingkup bagi pemeluknya. ${ }^{19}$

Hasil dari penilitian ini, bahwasanya teori humanistik merupakan sebuah rancangan mengenai manusia sebagai titik pusat keberadaan. Seperti halnya, sesuatu yang tidak bermakna ketika tidak adanya manusia. Sehubungan hal tersebut, penulis telah melaksanakan penelitian di SMP Muhammadiyah Al Mujahidin Gunung Kidul. Dalam proses pengumpulan data mengenai proses pembelajaran Pendidikan Agama Islam di era revolusi 4.0. dengan pendekatan humanistik, telah diuraikan oleh Hasnanto. ${ }^{20}$

SMP Muhammadiyah Al-Mujahidin merupakan gagasan yang tepat. Dengan berdirinya sebuah lembaga SMP Muhammadiyah Al Mujahidin menjadi banyak perhatian dari masyarakat sekitar, tentang perlu adanya sebuah lembaga pendidikan Islam yang

18 Dimas Indianto, Pendidikan Agama IslamDalam Revolusi Industri 4.0. (Proseding Seminar Nasional Prodi Pendidikan Agama Islam UMP tahun 2019, ISBN: 978-602- 6697-31-8), hlm. 112.

${ }^{19}$ Mulkhan, Abdul Munir S .U., Nalar Spiritual Pendidikan: Solusi Problem Filosofis Pendidikan Agama Islam, (Yogyakarta: PT Tiara Wacana Yogya, 2002), hlm. 51 .

${ }^{20}$ Hasnanto, Guru Pendidikan Agama Islam, dalam wawancara pada tanggal 14 November 2019. 
berkualitas, mendapatkan jaminan mutu pendidikan agama dan kualitas akademik secara integral. Dengan menggunakan model sekolah secara boarding school, SMP Muhammadiyah Al Mujahidin mulai berkembang dan dikenal oleh masyarakat. Pada tahap awal pendirian, rancangan yang dibuat oleh sekolah SMP Muhammadiyah Al Mujahidin dengan sistem Full day School dengan menerapkan pembelajaran agama Islam yang baik. SMP Muhammadiyah Al-Mujahidin merupakan salah satu lembaga yang sangat terkenal dengan prestasi dan model pembelajaran menggunakan 4.0. dalam pendekatan humanistik.

Konsep pembelajaran humanistik yang diterapkan di SMP Muhammadiyah Al Mujahidin secara umum menggunakan one day one tropy. Maksudnya adalah setiap siswa memiliki ciri khas yang berbeda, tidak bisa dikatakan semuanya itu pandai dalam matematika dan bahasa inggris. Pendidik melihat potensi setiap siswa untuk dikembangkan kedalam bakatnya. Proses pengembangan modelnya dengan munggunakan siko test seperti test psikoligi untuk mengetahui model belajar kinestetik atau tidak, audio atau tidak dan melakaukn test psikologi untuk mengetahui IQ dan cara belajar. Test psikologi ini dilaksanakan untuk semua siswa dan hasilnya dibagikan kepada semua guru, wali kelas untuk mengetahui cara model mengajar disetiap kelas.

Perubahan penerapan humanistik dilihat dari segi input. Contohnya nilai rata-rata NIM Ujian Nasional tahun ini 22 dan tahun sebelumnya 27. Perubahan ini tidak hanya dilihat dari nilai input akademik namun dilihat dari lomba-lomba yang ada. Proses pembelajaran dikelas tetap masuk kelas dan menggunakan presensi. Model pembelajaran dikelas menggunakan model diskusi dan cenderung menggunakan K 13 saintifik. Siswa belajar sebagai pusatnya ilmu bukan guru. Karena, kalau guru menggunakan model ceramah sebagai pusatnya ilmu siswa cenderung akan tidur. Pengalaman dari sini, pendidik memanfaatkan siswa untuk menyampaikan sumber materi pembelajaran. Alasan menggunakan pembelajaran 4.0. itu sendiri karena untuk memudahkan sesuatu teknologi. Contoh sederhanya ulangan harian menggunakan aplikasi teknologi dan akan langsung mengetahui hasil nilainya. Apakah siswa tersebut remidi atau tidak. 
Dalam menentukan kebijakan pendekatan humanistik pembelajaran Pendidikan Agama Islam di era revolusis 4.0. SMP Muhammadiyah Al Mujahidin Gunung Kidul menggunakan kontrak belajar yang tidak semerta-merta guru mengajarkan langsung A, B, C, D. Guru cenderung melihat keadaan siswa, apakah dengan menggunakan model pembelajaran seperti ini, siswa bisa mengikuti apa tidak. Jika siswa belum bisa mengikuti pembelajaran dengan metode yang diterapkan, guru mencoba menerapkan metode mengajar sesuai dengan kontrak belajar yang sudah disepakati diawal semester.

Salah satu contoh kebijakan dalam pembelajaran Pendidikan Agama Islam diera revolusi 4.0. dengan memanfaatkan sebuah aplikasi termasuk menggunakan media dan cenderung kepada mereka. Harapannya siswa tidak hanya mengakses media pembelajaran namun siswa juga bisa berkarya. Kalau sebelumnya siswa cenderung membaca pada bab yang akan dipelajari. Dan setelah semua membaca dan memahami dilanjut dengan pengambilan nilai harian dengan melaksanakan ulangan. Namun, mulai penerapan pembelajaran menggunakan era revolusi 4.0 siswa dituntut untuk menghasilkan sebuah aplikasi dari bab pembelajaran dengan kesepakatan apa yang akan dihasilkan dan dikembangkan dari materi ini.

Suatu tantangan yang dihadapi dalam pembelajaran Pendidikan Agama Islam diera revolusi 4.0. salah satunya banyak siswa yang belum bisa mengoperasikan komputer, karena untuk pelajaran teknologi informasi komputer sendiri dihapuskan dari kurikulum. Siswa cenderung bisa mengoperasikan handphone. Namun, ketika siswa akan mengikuti lomba sesuatu yang lebih detail berkaitan dengan 4.0. siswa tidak akan mampu. Pendidik berusaha mengajarkan ilmu teknologi informatika komputer dalam pembelajaran Pendidikan Agama Islam dengan memberitahu cara mengoperasikan komputer. Alasan pelajaran teknologi informatika komputer di hilangkan karena 4.0. ini sudah mencakup semua. Pada faktanya banyak siswa yang belum bisa mengoperasikan PTT, Video, Word dan Excel. Dengan model kerja kelompok semua mampu teratasi, satu sama lain akan saling mengajarkan tentang teori yang belum bisa. Mereka diajak kerja sama, misalnya yang satu tidak memiliki handphone atau tidak bisa menggunakan 196 Vol. 2, No. 2, Juli - Desember 2019 
handphone maka dengan berkelompok bias saling melengkapi. Dari sini bukan keahlian individu yang bisa melakukan semuanya, jadi cenderung kerjasama. Akhirnya mengoptimalkan potensi masingmasing seperti hanya yang tidak bisa merekam berarti yang direkam oleh orang lain.

Pendidik dalam mewujudkan siswa berkualitas didalam era revolusi dengan cara rajin belajar. Revolusi 4.0. baru terkenal perkembangannya dan mulai diseminarkan. Cara memanfaatkan era revolusi melihat kontrak belajar diawal semester dan potensi anak. Karena potensi anak yang tahun ini dengan tahun sebelumnya sering berbeda. Seperti hanya, potensi generasi siswa tahun lalu dengan yang namanya mengupload akun youtube mereka belum mengetahui sama sekali. Untuk generasi yang tahun ini, siswa sudah terbiasa mengupload akun youtoube dan membuat video. Pendidik memanfaatkan kontrak belajar di awal pembelajaran dengan menggunakan pretest dan mencari peluang untuk dikembangkan ke era evolusi 4.0. dengan membuat aplikasiaplikasi seperti aplikasi ujian online, ulangan harian dan tidak menghilangkan materi dari buku.

\section{KESIMPULAN}

Teori humanistik merupakan suatu pembelajaran yang dianggap sukses apabila peserta didik mampu memahami lingkungan serta kepribadiaanya. Dalam pelaksanaan pembelajaran, peserta didik berusaha dengan sungguh-sungguh supaya berhasil mencapai sebuah target dalam pembelajaran Pendidikan Agama Islam dengan aktualisasi diri dengan baik.

Eksistensi pembelajaran Pendidikan Agama Islam di era revolusi 4.0. dengan menggambarkan berbagai cara mengintegrasikan teknologi cyber baik secara fisik maupun tidak kedalam pembelajaran sangatlah bagus. Penerapan Humanistik dalam pembelajaran Pendidikan Agama Islam yang dilakukan oleh guru SMP Muhammadiyah Al Mujahidin menghasilkan hubungan antara manusia satu dengan manusia yang lain dengan kerja yang maksimal dan cukup baik. 


\section{REFERENSI}

Abdul Majid. Dian Andayani. Pendidikan Agama Islam Berbasis Kompetensi (Konsep dan Implementasi Kurikulum 2004). Bandung: Remaja Rosdakarya. 2006.

Agus Basri. Pendidikan Islam sebagai Penggerak Pembaharuan. Bandung: PT Al Ma’arif. 1984.

Agus Akmal, dkk. Pembelajaran Pendidikan Agama Islam Humanistik Dengan Pendekatan Active Learning di MTs $N 1$ Bombang . Jurnal Dirkursus Islam Volume .6. N0. 3. 2019.

Bambang Warsita. Teknologi Pembelajaran:landasan dan Aplikasinya. Jakarta: Rineka Cipta .2008.

Budi Agus Sumantri, Nurul Ahmad, Teori Belajar Humanistik Dan Implikasinya Terhadap Pembelajaran Pendidikan Agama Islam. Jurnal Pendidikan Dasar Volume 3. Nomor 2 September 2019.

Dimas Indianto. Pendidikan Agama Islam Dalam Revolusi Industri 4.0. (Proseding Seminar Nasional Prodi Pendidikan Agama Islam UMP tahun 2019. ISBN: 978-602-6697-31-8.

Hasnanto. Guru Pendidikan Agama Islam dalam wawancara pada tanggal 14 November 2019.

Mohammad Muclish Solichin. Teori Belajar Humanistik dan Aplikasinya Dalam Pendidikan Agama Islam. Jurnal Studi Islam al Studi Islam Volume. 5. No.1 Juni 2018.

Muhaimin dkk. Strategi Belajar Mengajar.Surabaya: Citra Media.1996. 
Mulkhan, Abdul Munir S.U. Nalar Spiritual Pendidikan: Solusi Problem Filosofis Pendidikan Agama Islam. Yogyakarta: PT Tiara Wacana Yogya. 2002.

Najamuddin P. Solong. Pengembangan Materi Pendidikan Agama Islam. Sleman: Teras, 2014.

Nana Syaodih Sukmadinata. Metodelogi Penelitian Pendidikan. Bandung: PT Remaja Reosdakarya.2017.

Nazarudin Rahman. Manajemen Pembelajaram, Implementasi Konsep, Karakteristik dan Metodologi Pendidikan Agama Iskam di Sekolah Umum. Yogyakarta: Pustaka Felicha, 2009.

Nurul Hidayati. Urgensi Pendidikan Islam di Era 4.0. article: may. 2019.

Ratna Syifaa Rahmahana. Psikologi Humanistik dan Aplikasi Pendidikan. El- Tarbawi: Jurnal Pendidikan Islam.

Rudi Susilana. Cipta Riyana. Media Pembelajaran (Hakikat, Pengembangan, Pemanfaatan dan Penilaian). Bandung : CV Wacana Prima. 2018.

S. Winataputra. Belajar dan Mengajar. Surakarta: Lima Aksara. 2008. Sigit Priatmoko. Memperkuat Eksitensi Pendidikan Islam di Era 4.0. Jurnal Studi Pendidikan Islam Volume. 1. No.2 Juli 2018.

Zakiyah Derajat. Ilmu Pendidikan Islam. Jakarta: Bumi Aksara. 2008. Zuhairini. Metode Pembelajaran Pendidikan Agama Islam. Malang: UIN Malang Press. 2004.

Zuhairini, dkk. Metodologi Pendidikan Agama Islam. Solo:Ramadhani. 1993. 